\title{
Aspek Perjanjian Lisensi Merek Pada Nota Kesepakatan Kerjasama Xie Xie Boba Indonesia
}

\author{
Cindy Fransisca Subagijo dan Ghansham Anand \\ csubagijo@gmail.com \\ Universitas Airlangga
}

\begin{abstract}
Many bubble tea shops like XIE XIE BOBA are developing their business using brand licensing. In branding licenses, the parties often make agreements only based on the principle of freedom of contract. They do not heed the minimum requirement provisions in the trademark license agreement, which is frequently happening that the trademark license agreement is not recorded and does not meet the minimum clauses. The purpose of this research is to analyze the characteristics of a trademark license agreement and analyze the legal consequences of a trademark license agreement that does not meet the minimum requirements. This research is legal research that solves legal issues by identifying legal problems, conducting legal reasoning, analyzing it, and providing solutions to the problem. The approach used in this research is the statute approach and the conceptual approach. The study found that despite trademark license agreement made based on the principle of freedom of contract, paying attention to the characteristics of the trademark license agreement and the minimum provisions stipulated in Law Number 20 of 2016 about Trademarks and Geographical Indications and Government Regulation Number 36 of 2018 concerning Registration of License Agreements. The legal consequence of the trademark license agreement that does not meet the minimum requirements is that there are no legal consequences for the third party. Although, trademark license agreement is still valid and only applies to the licensor and licensee.

Keywords: Brand; License; Trademark License Agreement.
\end{abstract}

\begin{abstract}
Abstrak
Banyak bisnis minuman boba sepertimerek XIEXIEBOBA yang sedang mengembangkan bisnisnya dengan cara lisensi merek. Dalam melakukan lisensi merek seringkali para pihak membuat perjanjian berdasarkan berdasarkan asas kebebasan berkontrak saja dan tidak memperhatikan ketentuan minimum yang harus termuat dalam perjanjian lisensi merek, yang seringkali terjadi adalah perjanjian lisensi merek tidak dicatatkan dan tidak memenuhi klausula minimum. Adapun tujuan dilakukannya penelitian ini yaitu untuk menganalisis karakteristik perjanjian lisensi merek dan menganalisis akibat hukum terhadap perjanjian lisensi merek yang tidak memenuhi ketentuan minimum. Penelitian ini adalah penelitian hukum yang memecahkan isu hukum yang dihadapi dengan cara mengidentifikasi masalah hukum, melakukan penalaran hukum, menganalisis masalah yang dihadapi kemudian memberikan pemecahan atas masalah hukum yang dihadapi. Pendekatan masalah yang digunakan dalam penelitian ini yaitu pendekatan peraturan perundangundangan (statute approach) dan pendekatan konseptual (conceptual approach). Dalam penelitian ini ditemukan bahwa perjanjian lisensi merek meskipun dibuat berdasarkan asas kebebasan berkontrak tetap harus memperhatikan karakteristik perjanjian lisensi merek dan ketentuan minimum yang diatur dalam Undang-Undang Nomor 20 Tahun 2016 tentang Merek dan Indikasi Geografis dan Peraturan Pemerintah Nomor 36 Tahun 2018 tentang Pencatatan Perjanjian Lisensi Kekayaan Intelektual terkait pencatatan dan klausula minimum perjanjian lisensi merek. Akibat hukum terhadap perjanjian lisensi merek yang tidak memenuhi ketentuan minimum adalah tidak memiliki akibat hukum bagi pihak ketiga tetapi perjanjian lisensi merek tersebut tetap sah dan hanya berlaku bagi pemberi lisensi dan penerima lisensi.
\end{abstract}

Kata Kunci: Merek; Lisensi; Perjanjian Lisensi Merek. 


\section{Pendahuluan}

Bisnis kuliner baik itu makanan maupun minuman merupakan salah satu bisnis yang dapat berkembang pesat di Indonesia. Di Indonesia, salah satu bisnis minuman yang berkembang pesat adalah bisnis minuman boba. Karena karakteristiknya tersebut, minuman boba semakin populer. Merek demi merek di Indonesia bermunculan satu per satu dan menawarkan menu ini, seperti halnya minuman boba dengan merek Xie-Xie Boba, Kamsia Boba, King Boba, Ni Hao Boba, dan masih banyak lagi. Bahkan di Indonesia, sudah beberapa kali diselenggarakan festival boba untuk memenuhi tingginya antusiasime para pecinta minuman ini. ${ }^{1}$

Menjamurnya berbagai bisnis minuman boba dengan merek yang ada, membuat pemilik bisnis minuman boba berkeinginan mengembangkan usaha dengan merek yang dimilikinya untuk lebih berkembang lagi. Selain itu diiringi juga dengan tingginya minat pelaku usaha yang baru untuk membuka bisnis minuman tersebut. Strategi bisnis yang dapat dipilih oleh para pemilik bisnis untuk mengembangkan bisnisnya seperti waralaba, kemitraan, ataupun lisensi. Kebanyakan dari pelaku usaha mengembangkan bisnisnya dengan model waralaba dan kemitraan tetapi mereka tidak mengerti dimana pada kenyataannya bisnis yang mereka kembangkan tersebut tidak memenuhi krieteria berdasarkan Peraturan Pemerintah Nomor 42 Tahun 2007 tentang Waralaba untuk dapat disebut sebagai waralaba dan Undang-Undang Nomor 20 Tahun 2008 tentang Usaha Mikro, Kecil dan Menengah untuk dapat disebut sebagai kemitraan, melainkan bisnis yang mereka kembangkan tersebut menggunakan cara lisensi.

Pemilik bisnis yang mempunyai hak merek atas bisnisnya tersebut dapat memberikan izin pada orang lain untuk menggunakan merek yang dimilikinya dengan cara lisensi untuk mengembangkan bisnis tersebut. Di lain hal dalam menawarkan paket bisnisnya banyak pemilik bisnis minuman boba menggunakan media sosial untuk membantu memasaran bisnisnya tersebut. Melalui media

\footnotetext{
${ }^{1}$ Go Biz, 'Manisnya Bisnis Minuman Boba \& 5 Tips Memulainya' <https://gobiz.co.id/ pusat-pengetahuan/tren-bisnis-minuman-boba/> accessed 16 September 2020.
} 
sosial, pelaku bisnis dapat membantu memasarkan bisnisnya tersebut dan juga menarik perhatian pelaku usaha baru untuk mencoba membuka bisnis tersebut. Terlebih lagi dengan adanya penawaran berupa paket bisnis yang ditawarkan dengan harga yang terjangkau dan menawarkan keuntungan yang relatif besar dengan jangka waktu yang cepat tentunya menarik perhatian para pelaku bisnis baru terlebih lagi didorong dengan adanya suatu merek yang sudah dikenal dalam masyarakat, tentunya ini merupakan sebuah keuntungan untuk memilih menajalankan bisnis tersebut.

Di Indonesia, merek dan lisensi diatur dalam Undang-Undang Nomor 20 Tahun 2016 Tentang Merek dan Indikasi Geografis (selanjutnya disebut UU 20/2016), Peraturan Pemerintah Nomor 36 Tahun 2018 Tentang Pencatatan Perjanjian Lisensi Kekayaan Intelektual (selanjutnya disebut PP 36/2018) dan Peraturan Menteri Hukum dan Hak Asasi Manusia Republik Indonesia Nomor 8 Tahun 2016 Tentang Syarat dan Tata Cara Permohonan Pencatatan Perjanjian Lisensi Kekayaan Intelektual (selanjutnya disingkat Permenkumham 8/2016). Berdasarkan Pasal 1 angka 1 UU 20/2016, merek adalah tanda yang dapat ditampilkan secara grafis berupa gambar, logo, nama, kata huruf, angka, susunan, warna, dalam bentuk 2 (dua) dimensi dan/atau 3 (tiga) dimensi, suara, hologram, atau kombinasi dari 2 (dua) atau lebih unsur tersebut untuk membedakan barang dan/atau jasa yang diproduksi oleh orang atau badan hukum dalam kegiatan perdagangan barang dan/atau jasa. Sedangkan yang dimaksud lisensi berdasarkan Pasal 1 angka 18 UU 20/2016 adalah izin yang diberikan oleh pemilik merek terdaftar kepada pihak lain berdasarkan perjanjian secara tertulis sesuai peraturan perundang-undangan untuk menggunakan merek terdaftar.

Menjalankan bisnis dengan lisensi tentunya harus didasari oleh dasar perjanjian tertulis sebagaimana ditentukan dalam Pasal 5 ayat 1 PP 36/2018. Perjanjian tersebut berupa perjanjian lisensi yang dibuat antara pemberi lisensi dan penerima lisensi yang mana para pihak tersebut menyepakati ketentuan-ketentuan yang sudah dibuat dalam perjanjian. Perjanjian lisensi tersebut merupakan alasan 
yang sah dan legal untuk memakai merek orang lain. ${ }^{2}$ Terkait dengan hal tersebut, terdapat salah satu bisnis minuman boba yang ada di Indonesia dengan merek XIE XIE BOBA yang sampai saat ini bisnis minuman boba tersebut telah memiliki kurang lebih 100 cabang diwilayah Indonesia. ${ }^{3}$ Dalam menjalankan bisnis minuman boba tersebut pihak XIE XIE BOBA sebagai pemilik bisnis memberikan penawaran paket bisnis untuk menggunakan merek yang dimilikinya tersebut berupa PDF kepada calon pelaku usaha baru atau calon penerima lisensi. Penawaran tersebut berupa harga paket usaha, keuntungan memilih usaha XIE XIE BOBA, daftar menu XIE XIE BOBA, peralatan yang didapatkan, asumsi balik modal dan langkah-langkah untuk menjadi penerima hak merek XIE XIE BOBA. Dalam langkah-langkah menjadi penerima lisensi tersebut, XIE XIE BOBA hanya menuliskan bahwa calon penerima lisensi dapat langsung menjadi partner bisnisnya hanya dengan membayar paket bisnis XIE XIE BOBA (termasuk biaya kirim). Kemudian pihak XIE XIE BOBA akan mengirimkan paket yang dipilih dan dikirimkan sesuai dengan alamat calon penerima dan penerima lisensi dapat membuka bisnis minuman dengan merek XIE XIE BOBA.

Calon penerima lisensi yang sepakat untuk menggunakan merek XIE XIE BOBA dapat langsung menjalankan bisnis minuman boba tersebut tanpa adanya perjanjian khusus sebagai dasar untuk memakai izin merek minuman boba tersebut. Menurut pelaku usaha $\mathrm{X}$ dan $\mathrm{Y}$ dalam menjalankan bisnis minuman boba dengan merek XIE XIE BOBA hanya berdasarkan kesepakatan terhadap penawaran paket binis yang ditawarkan dan kesepakatan para pihak untuk menggunakan merek XIE XIE BOBA tersebut tidak dituangkan dalam suatu perjanjian khusus yang berbentuk tertulis ${ }^{4}$ sebagaimana ditentukan dalam Pasal 5 ayat (1) PP 36/2018.

${ }^{2}$ Agung Sujatmiko, 'Peran Penting Perjanjian Lisensi Dalam Melindungi Merek Terkenal' (2010) 22 Mimbar Hukum.[119].

${ }^{3}$ Xie Xie Boba Indonesia, 'Franchise Boba Paling Laris 2020' (Xie Xie Boba Indonesia, <https:/ / $w w w . x i e x i e b o b a . c o m /$ ?utm_source=google\&utm_medium $=$ cpc\&utm_campaign=8009781075 $\&$ agroup $=100543367018 \&$ utm_term $=\&$ feeditemid $=\&$ apos $=\&$ gclid $=C j w K C A j w q M$ L6BRAHEiw A dqu MnYHDNrqqSuEoa 7cIuv6 H58 Azy V CVrbX3W33 B CIkmiW V sIA7yzsWfkxoCtXwQAvD_BwE> accessed 4 September 2020.

${ }^{4}$ Wawancara dengan $X$ dan $Y$ yang merupakan pelaku usaha Xie-Xie Boba di Surabaya, 4 September 2020. 
Baik pelaku usaha $X$ dan $Y$, keduanya tidak mengetahui adanya perjanjian khusus dalam menjalankan bisnis minuman boba dengan merek XIE XIE BOBA tersebut.

Kenyataannya dalam menjalankan bisnis tersebut, XIE XIE BOBA memiliki suatu perjanjian khusus yang berbentuk tertulis berupa Nota Kesepakatan Kerjasama XIE XIE BOBA INDONESIA. Perjanjian khusus yang berupa Nota Kesepakatan Kerjasama tersebut tidak diketahui dan diberikan kepada penerima lisensi, sehingga penerima lisensi tidak mengetahui isi dari perjanjian khusus tersebut. Perjanjian khusus tersebut akan diberikan kepada penerima lisensi apabila penerima lisensi bertanya dan meminta, jika tidak pemilik bisnis tidak memberikan perjanjian tersebut. Sedangkan perjanjian khusus tersebut seharusnya diketahui oleh kedua belah pihak, karena perjanjian tersebut menyangkut dan mengikat kedua belak pihak.

Perjanjian khusus yang berupa Nota Kesepakatan Kerjasama yang dibuat oleh pihak XIE XIE BOBA tersebut hanya mengatur mengenai pernyataan jaminan, dukungan, syarat menjadi penerima kemitraan, kewajiban, masa kerjasama, paket kemitraan, nilai investasi, cara pembayaran, lokasi usaha, rahasia dagang, kepemilikan hak, perubahan sistem, sengketa dengan pihak ketiga, pembatalan dan force majure. Perjanjian khusus yang dibuat oleh pihak XIE XIE BOBA tersebut tidak memenuhi klausula-klausula minimal yang ditentukan menurut penjelasan Pasal 7 ayat (2) PP 36/2018. Selain itu suatu perjanjian lisensi menurut Pasal 42 ayat (3) UU 20/2016 diwajibkan untuk dicatatkan ke Menteri sedangkan pada kenyataannya perjanjian khusus XIE XIE BOBA tersebut tidak dilakukan pencatatan ke Menteri sehingga perjanjian tersebut juga tidak memenuhi ketentuan syarat minimum untuk dapat dikategorikan sebagai perjanjian lisensi yang ditentukan oleh UU 20/2016.

Berdasarkan latar belakang tersebut terdapat permasalahan diantaranya yaitu apa karakteristik perjanjian lisensi merek XIE XIE BOBA dan akibat hukum terhadap perjanjian lisensi merek XIE XIE BOBA yang tidak memenuhi syarat minimum.

\section{MetodePenelitian}

Tipe penelitian hukum dalam penelitian hukum ini menggunakan doctrinal legal research yaitu suatu proses menjawab isu hukum dengan berpedoman pada 
prinsip-prinsip hukum, aturan-aturan hukum, maupun doktrin-doktrin hukum. ${ }^{5}$ Sedangkan pendekatan masalah yang digunakan dalam menganalisis permasalahan dalam penelitian ini adalah pendekatan perundang-undangan (statute approach) dan pendekatan konseptual (conceptual approach). Pendekatan perundang-undangan (statue approach) merupakan pendekatan yang dilakukan dengan berdasarkan semua undang-undang dan regulasi yang berkaitan dengan isu hukum yang sedang diangkat. Adapun perudang-undangan yang digunakan di dalam penelitian ini yaitu: Burgerlijk Wetboek (BW), UU 20/2016, PP 36/2018, Permenkumham 8/2016. Sementara pendekatan konseptual dalam tesis ini dilakukan melalui penelusuran terhadap konsep dan doktrin yang berhubungan dengan merek, lisensi, dan perjanjian lisensi.

\section{Karakteristik Perjanjian Lisensi Merek Xie-Xie Boba}

Salah satu cara yang dapat dilakukan oleh pemilik merek untuk mengembangkan bisnisnya yaitu dengan memberikan izin kepada pihak lain untuk menggunakan merek miliknya. Pemberian izin tersebut dilakukan dengan cara lisensi. Definisi lisensi menurut Pasal 1 angka 18 UU 20/2016 adalah izin yang diberikan oleh pemilik merek terdaftar kepada pihak lain berdasarkan perjanjian secara tertulis sesuai peraturan perundang-undangan untuk menggunakan merek terdaftar. Sedangkan menurut Gunawan Widjaja, lisensi adalah suatu bentuk hak untuk melakukan suatu atau serangkaian tindakan atau perbuatan, yang diberikan oleh mereka yang berwenang dalam bentuk izin. Tanpa adanya izin tersebut, maka tindakan atau perbuatan tersebut merupakan tindakan yang terlarang, yang tidak sah dan merupakan perbuatan melawan hukum. ${ }^{6}$

Terkait dengan semua pengertian tentang lisensi tersebut diatas dapat disimpulkan bahwa lisensi merupakan suatu pemberian izin dari pemberi lisensi untuk menggunakan HKI (selanjutnya disebut Hak Kekayaan Intelektual) yang dimilikinya kepada penerima lisensi berdasarkan suatu perjanjian lisensi. Jika

\footnotetext{
${ }^{5}$ Peter Mahmud Marzuki, Penelitian Hukum: Edisi Revisi (Prenada Media 2017).[1].

${ }^{6}$ ibid. [3].
} 
dikaitkan dengan merek maka yang dimaksud dengan lisensi merek adalah pemberian izin yang dari pemberi lisensi merek untuk menggunakan hak merek yang dimiliki kepada penerima lisensi merek berdasarkan suatu perjanjian lisensi merek. Tentunya dengan adanya lisensi dapat berfungsi menerobos eklsklusifitas hak merek, agar orang lain dapat memakai suatu merek secara aman dan legal. ${ }^{7}$

Pasal 42 ayat (1) UU 20/2016 menyatakan bahwa: "Pemilik merek terdaftar dapat memberikan lisensi kepada pihak lain untuk menggunakan merek tersebut baik sebagian maupun seluruh jenis barang dan/atau jasa". Sedangkan dalam Pasal 3 PP 36/2016 menyatakan bahwa: “Pemegang HKI berhak memberikan lisensi kepada pihak lain untuk melaksanakan hak eksklusif miliknya". Dalam lisensi, pemilik HKI bukan mengalihkan HKI yang dimilikinya tetapi hanya memberikan hak yaitu berupa hak eksklusifnya kepada pihak lainuntuk dapat menggunakan. Lisensi merek merupakan bagian dari hak eksklusif merek, dimana pemilik hak merek masih bisa menggunakan hak mereknya untuk memproduksi barang dan/ atau jasa dan memberikan hak untuk memberi izin pada pihak lain untuk menggunakan merek yang bersangkutan. ${ }^{8}$ Dengan adanya lisensi tentunya melindungi hak merek yang dimiliki oleh pemilik merek selain hak merek itu sendiri juga dilindungi oleh undang-undang.

Jenis lisensi yang terkait HKI, secara teoritis lisensi terdiri dari:

a. Lisensi sukarela (voluntarylicensing) didasarkan pada asas kebebasan berkontrak (freedom of contract);

b. Lisensi tidak sukarela (non-voluntary licensing) lazimnya diberikan melalui putusan pengadilan dalam kasus persinggungan antara Hukum Anti-monopoli dan Hukum HKI, terutama jika pemegang HKI bertindak anti-kompetisi;

c. Lisensi wajib (compulsory licensing) merupakan lisensi wajib yang sudah ditetapkan secara khusus dalam undang-undang, lazimnya dengan tujuan untuk kepentingan umum dengan pembayaran kompensasi yang layak. ${ }^{9}$

\footnotetext{
${ }^{7}$ Agung Sujatmiko, Op.Cit.[15].

8 ibid.[19].

${ }^{9}$ Rahmi Jened, Hukum Merek (Trademark Law) Dalam Era Global Dan Integrasi Ekonomi) (Kencana Prenadamedia Group 2015).[197].
} 
Dalam kaitannya dengan lisensi sukarela ada 2 (dua) varian utama, yaitu:

a. Lisensi eksklusif

Suatu perjanjian dengan pihak lain untuk melisensikan sebagian hak kekayaan intelektual tertentu kepada penerima lisensi untuk jangka waktu yang ditentukan dan biasanya lisensi diberlakukan untuk daerah yang ditentukan. Pemberi lisensi biasanya memutuskan untuk tidak memberikan hak kekayaan intelektual tersebut kepada pihak lain dalam daerah terseut untuk jangka waktu berlakunya lisensi kecuali kepada pemegang lisensi eksklusif.

b. Lisensi non eksklusif

Suatu bentuk lisensi yang memberikan kesempatan kepada pemilik lisensi yang memberikan lisensi hak kekayaan intelektualnya kepada pemakai lisensi lainnya dan juga untuk menambah jumlah pemakai lisensi dalam daerah yang sama. Lisensi non eksklusif dapat diberikan kepada berbagai pihak oleh pemegang atau pemilik lisensi sesuai dengan atau berdasarkan perjanjian. Lisensi seperti ini hanya dapat diperoleh seseorang semata-mata berdasarkan perjanjian dengan pihak pemilik atau pemegang lisensi. ${ }^{10}$

Lisensi sukarela diatur secara tegas dalam Pasal 42 sampai dengan Pasal 45 UU 20/2016. Dalam Pasal 43 UU 20/2016 menyatakan bahwa: “Pemilik merek terdaftar yang telah memberikan lisensi kepada pihak lain tetap dapat menggunakan sendiri atau memberikan lisensi kepada pihak ketiga lainnya untuk menggunakan merek tersebut, kecuali bila diperjanjikan lain". Bahwa dari Pasal 43 UU 20/2016 dapat disimpulkan pembentuk undang-undang menetapkan bahwa pasal tersebut merupakan lisensi sukarela yang bersifat non eksklusif, namun apabila para pihak menghendaki membuat perjanjian lisensi secara eksklusif, hal itu tidak dilarang karena dalam Pasal 43 UU 20/2016 disebutkan dapat diperjanjikan lain. Hal ini menunjukan bahwa perjanjian lisensi dibuat berdasarkan prinsip kebebasan berkontrak. Apabila dilihat dari perjanjian XIE XIE BOBA yang didapatkan oleh penulis, di dalam perjanjian tersebut tidak diatur dan

${ }^{10}$ Tim Lindsey, Hak Kekayaan Intelektual Suatu Pengantar (Alumni 2002).[97]. 
tidak dijelaskan secara jelas dan rinci bahwa perjanjian XIE XIE BOBA termasuk lisensi sukarela yang bersifat eksklusif atau non eksklusif. Tetapi jika dilihat dari kenyataannya XIE XIE BOBA telah memiliki lebih dari 100 cabang di Indonesia ${ }^{11}$ sehingga penulis menyimpulkan LF sebagai pemiliki merek XIE XIE BOBA memberikan lisensi tidak hanya kepada BP, tetapi pihak lain juga diberikan izin oleh LF untuk menggunakan merek yang dimilikinya tersebut. Dengan adanya 100 outlet bisnis minuman boba dengan merek XIE XIE BOBA yang dijalankan oleh pihak lain, menunjukan bahwa lisensi merek yang diberikan oleh LF bersifat non eksklusif karena tidak terbatas pada satu orang saja.

Pihak-pihak yang melakukan lisensi ada 2 (dua) yaitu: ${ }^{12}$

\section{a. Licensor (Pemberi Lisensi)}

The person who gives or grants a license. (Pemberi lisensi adalah pihak yang menjual atau memberikan lisensi).

\section{b. Licensee (Penerima Lisensi)}

Person to whom a license has been granted. (Pihak yang menerima lisensi).

Suatu perjanjian tentunya dibuat minimal oleh 2 (dua) pihak yang mengikat satu sama lain untuk melaksanakan suatu prestasi. Tentunya dalam membuat perjanjian lisensi merek yang dimaksud para pihak adalah para pihak dalam menjalankan lisensi yaitu pemberi lisensi dengan penerima lisensi. Pemberi lisensi merupakan pihak yang memiliki hak merek atas suatu barang dan/atau jasa yang memberikan izin kepada pihak lain untuk dapat menggunakan hak yang dimilikinya berdasarkan perjanjian lisensi merek. Sedangkan penerima lisensi merupakan pihak lain yang menerima izin dari pemberi lisensi untuk menggunakan hak merek yang dimiliki oleh pemberi lisensi berdasarkan perjanjian lisensi merek. Dalam hal ini, baik pemberi lisensi ataupun penerima lisensi dapat dilakukan oleh perorangan atau badan hukum.

${ }^{11}$ Xie Xie Boba Indonesia, 'Franchise Boba Paling Laris 2020' (Xie Xie Boba Indonesia, 2020) <https://www.xiexieboba.com/?utm_source=google\&utm_medium=cpc\&utm_campaign= 8009781075\&agroup=100543367018\&utm_term=\&feeditemid = \&apos=\&gclid =CjwKC AjwqML6B RAHEiw AdquMnYHDNrqqSuEoa7cIuv6H58AzyVCVrbX3W33BCIkmiWVsIA7yzsWfkxoCtX wQAvD _BwE> accessed 1 December 2020.

${ }^{12}$ Gunawan Widjaja, Seri Hukum Bisnis Lisensi (Raja Grafindo Persada 2001).[8]. 
Lisensi diberikan berdasarkan perjanjian lisensi dalam bentuk tertulis antara pemberi lisensi dengan penerima lisensi sebagaimana diatur dalam Pasal 5 PP 36/2018, sehingga dasar diberikannya lisensi adalah perjanjian lisensi. Apabila dikaitkan dengan merek maka yang dimaksud dengan perjanjian lisensi merek adalah perjanjian yang dibuat antara 2 (dua) pihak yaitu pihak pemilik merek sebagai pemberi lisensi merek dengan pihak lain sebagai penerima lisensi merek.

Bagi pemilik merek, perjanjian lisensi dapat bermakna dalam 2 (dua) segi yaitu segi yuridis dan segi ekonomi. Dari segi yuridis perjanjian lisensi dapat menjadi perlindungan hukum atas merek yang dimilikinya, disamping adanya undang-undang. Dari segi ekonomi, perjanjian lisnsi memberikan keuntungan bagi pemilik merek, karena pemilik merek memiliki hak merek yang dimilikinya untuk memberikan izin kepada pihak lain untuk menggunakan hak mereknya atas dasar perjanjian lisensi.

Perjanjian lisensi merek merupakan perjanjian yang tidak diatur secara khusus dalam BW. Namun perjanjian lisensi merek timbul dari asas kebebasan berkontrak, sehingga perjanjian lisensi merek itu dibuat berdasarkan kebebasan berkontrak. Menurut Pasal 1338 BW menyatakan bahwa: "Semua perjanjian yang dibuat secara sah akan mengikat semua pihak bagaikan undang-undang, sehingga setiap orang dapat membuat perjanjian dengan syarat yang ditentukan masing-masing". Apabila perjanjian lisensi merek memenuhi 4 syarat sahnya suatu perjanjian yang diatur dalam Pasal 1320 BW, sesuai dengan Pasal 1338 BW, apabila suatu perjanjian dibuat secara sah, maka berlakulah ia sebagai undangundang bagi pihak yang membuatnya.

Perjanjian lisensi merek juga harus memenuhi klausula minimum yang telah ditentukan dalam Pasal 7 ayat (2) PP 36/2018 yang mana suatu perjanjian lisensi merek harus mencantumkan hal-hal yang dimuat sekurang-kurangnya yaitu:

a. tanggal, bulan, tahun dan tempat perjanjian lisensi ditandatangani;

b. nama dan alamat pemberi lisensi dan penerima lisensi;

c. objek perjanjian lisensi;

d. ketentuan mengenai lisensi bersifat eksklusif atau non ekslusif, termasuk sublisensi;

e. jangka waktu perjanjian lisensi; 
f. wilayah berlakunya perjanjian lisensi;

g. pihak yang melakukan pembayaran biaya tahunan untuk paten.

Pertama, tanggal, bulan, tahun dan tempat perjanjian lisensi ditandatangani, yaitu waktu dan tempat pada saat pemberi lisensi dan penerima lisensi mengadakan perjanjian lisensi merek. Kedua, nama dan alamat pemberi lisensi dan penerima lisensi, yaitu identitas yang jelas pemilik hak merek atau pihak lain yang mengadakan perjanjian lisensi merek. Ketiga, obyek perjanjian lisensi, yaitu jenis HKI yang dilisensikan berupa hak atas merek. Keempat, ketentuan mengenai lisensi bersifat eksklusif atau non eksklusif, yaitu yang menentukan suatu lisensi apakah hanya berlaku untuk pemiliki hak atas merek itu sendiri ataukah berlaku kepada pihak lain karena telah diberikan izin dari pemilik hak atas merek untuk menggunakan hak yang dimilikinya tersebut. Kelima, jangka waktu perjanjian lisensi, yaitu batasan waktu mulai dan berakhirnya perjanjian terhitung sejak perjanjian lisensi merek tersebut ditanda tangani oleh kedua belah pihak. Keenam, wilayah berlakunya perjanjian lisensi, yaitu batasan wilayah yang diberikan pemberi lisensi kepada penerima lisensi untuk menggunakan izin atas hak merek yang diberikannya. Ketujuh, pihak yang melakukan pembayaran biaya tahunan untuk paten, yaitu kewajiban penerima lisensi untuk membayar biaya atas penggunaan izin hak atas merek yang dipakainya.

Sementara menurut Rahmi Jened, perjanjian lisensi sekurang-kurangnya harus memuat hal-hal sebagai berikut:

1. nama dan alamat lengkap para pihak;

2. merek dan nomor pendaftarannya dari merek yang menjadi objek perjanjian;

3. ketentuan hal-hal sebagai berikut:

a. jangka waktu perjanjian lisensi, yang mencangkup berapa lama dan dapat atau tidaknya jangka waktu diperpanjang;

b. penggunaan merek yang diberikan lisensi untuk seluruh atau sebagain;

c. penggunaan mereknya untuk seluruh atau sebagian jenis barang dan/atau jasa yang termasuk dalam satu kelas;

d. jumlah royalti dan tata cara pembayarannya;

e. dapat atau tidaknya penerima lisensi memberikan lisensi lebih lanjut kepada pihak ketiga; 
74 | Cindy Fransisca dan Ghansham Anand: Aspek Perjanjian Lisensi...

f. kewajiban pemberi lisensi untuk melakukan pengawasan dan pembinaan terhadap mutu barang yang diproduksi dan diperdagangkan;

g. batas wilayah berlakunya perjanjian lisensi. ${ }^{13}$

Menurut Gunawan Widjaja, hal-hal yang diatur dalam perjanjian lisensi adalah sebagai berikut:

1. identifikasi dari pihak pemberi lisensi dan pihak penerima lisensi;

2. identifikasi atas jenis HKI yang dilisensikan;

3. luasnya ruang lingkup HKI yang dilisensikan;

4. tujuan pemberian lisensi HKI;

5. eksklusifitas pemberian lisensi;

6. spesifikasi khusus yang berhubungan dengan wilayah pemberian lisensi, baik dalam bentuk kewenangan untuk melakukan produksi dan/atau untuk melaksanakan penjualan dari barang dan/atau jasa yang mengandung HKI yang dilisensikan;

7. hak pemberi lisensi atas laporan-laporan berkala dan untuk melaksanakan inspeksi-inspeksi atas pelaksanaan jalannya pemberian lisensi dan kewajiban penerima lisensi untuk memenuhi;

8. ada tidaknya kewajiban bagi penerima lisensi untuk membeli barang modal tertentu ataupun barang-barang tertentu lainnya dalam rangka pelaksanaan lisensi dari pemberi lisensi;

9. pengawasan oleh pemberi lisensi;

10. kerahasiaan atas HKI yang dilisensikan (confidentiality);

11. ketentuan mengenai non kompetisi (non competition clause);

12. kewajiban memberikan perlindungan atas HKI yang dilisensikan;

13. kewajiban pendaftaran lisensi;

14. kompensasi dalam bentuk royalty dan pembayaran;

15. pilihan hukum;

16. penyelesaian perselisihan;

17. pengakhiran pemberian lisensi. ${ }^{14}$

Meskipun menurut Rahmi Jened dan Gunawan Widjaja mengatur mengenai halhal yang diatur dalam perjanjian lisensi sebagaimana telah diuraikan diatas, tetapi menurut Pasal 7 ayat (2) PP 36/2018 klausula minimum merupakan salah satu yang harus ada dalam suatu perjanjian lisensi sehingga ketentuan Pasal 7 ayat (2) PP 36/2018 harus dipenuhi dan tidak boleh disimpangi dalam membuat suatu perjanjian lisensi.

\footnotetext{
${ }^{13}$ Rahmi Jened, Op.Cit.[60].

${ }^{14}$ Gunawan Widjaja, Op.Cit.[17-30].
} 
Akibat Hukum Terhadap Perjanjian Lisensi Merek Xie-Xie Boba Yang Tidak Memenuhi Syarat Minimum

Setiap perbuatan yang dilakukan tentu memiliki sebab dan akibat. Perjanjian lisensi merek merupakan perbuatan yang tentunya jika tidak memenuhi ketentuan minimum akan menimbulkan akibat hukum tertentu. Berdasarkan ketentuan Pasal 42 ayat (3) dan ayat (4) UU 20/2016, suatu perjanjian lisensi merek wajib untuk dicatatkan oleh Menteri dan diumumkan dalam berita resmi merek. Apabila suatu perjanjian lisensi merek tidak dicatatkan dan tidak diumumkan maka mempunyai akibat hukum terhadap pihak ketiga sebagaimana diatur dalam Pasal 42 ayat (5) UU 20/2016. Kata "pihak ketiga" dalam Pasal 42 ayat (5) UU 20/2016 dapat diartikan terlalu luas, sehingga perlu dipertimbangkan untuk makna dari kata "pihak ketiga" tersebut agar semakin jelas siapa subjek yang diaturnya. Salah satu rujukan yang dapat digunakan terkait pihak ketiga adalah ketentuan mengenai recording of assignments yang ada dalam hukum paten dan merek di Amerika Serikat, yang mengatakan bahwa:

"The office records assignments, grants, and similar instruments sent to it for recording, and the recording serves as notice. If (it) ... is not recorded in the office within three months from its date, it is void against a subsequent purchaser for a valuable consideration without notice, unless it is recorded prior to tohe subsequent purchase". ${ }^{15}$

Berdasarkan penjelasan tersebut diatas, "pihak ketiga" adalah subsequent purchaser atau pihak yang menerima lisensi selanjutnya dari penerima lisensi awal. Secara sederhana dapat diilustrasikan sebagai berikut: A memberi lisensi kepada B. B kemudian meberikan lisensi kepada C. Jika perjanjian lisensi tidak dicatatkan, maka B tidak berhak memberi lisensi kepada $C$, atau dapat dinyatakan bahwa perjanjian lisensi antara B dan C adalah batal demi hukum, karena tidak dipenuhinya peraturan perundang-undangan yang tidak memenuhi syarat sahnya perjanjian terkait kausa yang diperbolehkan.

\footnotetext{
${ }^{15}$ Brian Prastoyo, 'Akibat Hukum Pencatatan Perjanjian Lisensi' < https:/ / staff.blog.ui.ac.id/ brian.amy/2008/07/15/akibat-hukum-pencatatan-perjanjian-lisensi/> accessed 6 January 2021.
} 
76 Cindy Fransisca dan Ghansham Anand: Aspek Perjanjian Lisensi...

Suatu perjanjian lisensi wajib untuk dicatatkan dan diumumkan oleh Menteri, tidak hanya untuk melindungi kepentingan pemilik merek atau pemberi lisensi dan penerima lisensi saja tetapi juga pihak ketiga, karena dengan dicatatkan dan diumumkannya perjanjian lisensi merek maka perjanjian tersebut memiliki akibat hukum bagi pihak ketiga sebagaimana diatur dalam Pasal 42 ayat (5) UU 20/2016. Di sisi lain ketika perjanjian lisensi merek dicatatkan dan diumumkan maka perjanjian lisensi merek tersebut juga mempunyai kekuatan hukum yang mengikat bagi pemberi lisensi, penerima lisensi dan juga pihak ketiga. Apabila perjanjian lisensi merek tidak dicatatkan dan tidak diumumkan oleh para pihak maka perjanjian lisensi tersebut hanya mengikat bagi para pihak yang melakukan suatu perjanjian lisensi tersebut yaitu pihak pemberi lisensi dan pihak penerima lisensi, dan tidak mengikat pihak ketiga sehingga dapat disimpulkan juga perjanjian lisensi merek tersebut tetap sah bagi pemberi lisensi dan penerima lisensi tetapi hanya tidak mempunyai akibat hukum bagi pihak ketiga.

Sedangkan jika dilihat pada perjanjian XIE XIE BOBA yang didapatkan oleh penulis, para pihak dalam perjanjian XIE XIE BOBA tidak melakukan pencatatan perjanjian lisensi merek, sehingga akibat hukum terhadap perjanjian XIE XIE BOBA yang tidak memenuhi ketentuan minimum menurut UU 20/2016 adalah perjanjian XIE XIE BOBA tersebut tidak mempunyai akibat hukum bagi pihak ketiga dan perjanjian tersebut hanya berlaku bagi para pihak yang dalam hal ini adalah LF sebagai pemberi lisensi dan BP sebagai penerima lisensi.

Sementara itu juga perjanjian XIE XIE BOBA yang didapatkan oleh penulis selain tidak memenuhi kewajiban pencatatan perjanjian lisensi merek perjanjian XIE XIE BOBA sebagaimana diatur dalam Pasal 7 ayat (1) PP 36/2018 juga tidak memenuhi ketentuan minimum dalam PP 36/2018 terkait klausula minimum yang diatur dalam Pasal 7 (ayat) 2 PP 36/2018. Perjanjian XIE XIE BOBA yang tidak memenuhi ketentuan pencatatan perjanjian lisensi merek sebagimana diatur dalam Pasal 7 ayat (1) PP 36/2018 memiliki akibat hukum yang sama sebagimana diuraikan pada sub bab sebelumnya yang tidak memenuhi ketentuan minimum UU 20/2016. Sedangkan terkait tidak dipenuhinya ketentuan minimum terkait 
klausula minumum, 7 (tujuh) klausula sebagaimana diatur dalam Pasal 7 ayat (2) PP 36/2018 tersebut merupakan klausula minimum sehingga harus ada dalam perjanjian lisensi merek. Dalam hal ini perjanjian XIE XIE BOBA tidak memenuhi ketentuan Pasal 7 ayat (2) huruf d PP 36/2018 terkait klausula mengenai sifat perjanjian lisensi yang bersifat eksklusif atau non eksklusif. Terkait dengan sifat eksklusif atau non ekslusif dari perjanjian lisensi merek merupakan hal yang penting sehingga termasuk dalam klausula pokok yang harus ada dalam suatu perjanjian lisensi merek. Menurut Y. Sogar Simamora, jantung dari suatu perjanjian adalah klausula yang diatur dalamnya, yang mengikat kedua belah pihak sekalipun ada batas-batas tertentu. ${ }^{16}$ Oleh karena itu klausula yang diatur dalam peraturan perundang-undangan merupakan hal yang penting karena merupakan jantung dari perjanjian itu sendiri. Tetapi seringkali suatu perjanjian lisensi merek yang dibuat oleh para pihak hanya memuat hal-hal pokoknya saja tetapi bukan memuat klausula pokoknya, sehingga perjanjian lisensi tersebut tidak bisa sempurna.

Klausula dalam suatu perjanjian prinsipnya dibagi menjadi 2 (dua) yaitu klausula pokok dan klausula penunjang. Klausula pokok merupakan klausula yang mengatur unsur yang essensial dalam suatu perjanjian. Sedangkan klausula penunjang yang lazim disebut technical housekeeping clause adalah klausula yang menunjang atau melengkapi klausula pokoknya. ${ }^{17}$ Apabila dalam hal ini sifat eksklusif dan non ekslusif dari suatu perjanjian termasuk dalam klausula pokok, hal tersebut terjadi karena sifat eksklusif dan non eksklusif termasuk unsur yang essensial dalam suatu perjanjian. Unsur esensial merupakan unsur yang mutlak harus ada dalam suatu perjanjian. ${ }^{18}$ Dikarenakan termasuk dalam unsur essensial maka sifat eksklusif dan non ekslusif tersebut merupakan klausula yang harus ada dan penting dalam suatu perjanjian lisensi. Pertama karena sifat eksklusif atau non eksklusif menentukan apakah pemberi lisensi hanya memonopoli hak atas merek

\footnotetext{
${ }^{16}$ Y. Sogar Simamora, Hukum Kontrak Prinsip-Prinsip Hukum Kontrak Pengadaan Barang Dan Jasa Pemerintah Di Indonesia (Laksbang Pressindo 2017).[247].

17 ibid.[246].

${ }^{18}$ Agus Yudha Hernoko, Hukum Perjanjian: Asas Proporsionalitas Dalam Kontrak Komersial (Prenadamedia Group 2014).[225].
} 
yang dimilikinya sendiri atau memberikan izin kepada pihak lain sebagai penerima lisensi untuk menggunakan hak atas merek yang dimilikinya dan memungkinkan untuk penerima lisensi dapat memberikan sublisensi kepada pihak lain atau tidak. Kedua terkait dengan pengajuan klaim apabila ada pelanggaran terhadap hak atas merek, apabila perjanjian lisensi bersifat eksklusif dan terjadi pelanggaran terhadap hak atas merek maka penerima lisensi dapat diajukan klaim. Sedangkan jika perjanjian lisensi bersifat non ekslusif maka penerima lisensi tidak diberikan hak untuk mengajukan klaim dan menegakkan hak atas merek yang didapatkannya tersebut. Apabila sifat eksklusif dan non ekslusif dari suatu perjanjian termasuk dalam klausula penjunjang, maka sifat eksklusif atau non eksklusif tersebut hanya melengkapi klausula pokok lainnya dalam perjanjian lisensi merek tersebut. Walaupun bersifat melengkapi tidak berarti klausula sifat eksklusif atau non eksklusif tersebut tidak penting, karena tidak lengkapnya klausula penunjang dapat merugikan salah satu pihak. Oleh karena itu lebih baik sifat eksklusif atau non eksklusif suatu perjanjian lisensi merek masuk dalam klausula minimum yang harus ada dalam perjanjian lisensi merek untuk memenuhi ketentuan Pasal 7 ayat (2) PP 36/2018 dan untuk mengurangi kemungkinan terjadi kerugian oleh salah satu pihak.

Di sisi lain perjanjian XIE XIE BOBA juga tidak dapat dikategorikan sebagai perjanjian kemitraan karena XIE XIE BOBA bukan termasuk kemitraan. Hal tersebut disebabkan LF sebagai pemilik bisnis minuman XIE XIE BOBA tidak memenuhi ketetentuan untuk dapat disebut sebagai usaha besar sebagaimana dimaksud dalam Pasal 1 angka 4 UU UMKM. Jika LF adalah perorangan dan bukan merupakan usaha besar maka LF juga bukan termasuk subjek kemitraan sehingga otomatis perjanjian XIE XIE BOBA yang didapatkan oleh penulis bukan merupakan perjanjian kemitraan. Selain itu juga perjanjian yang dibuat oleh pihak XIE XIE BOBA berjudul Nota Kesepakatan Kerjasama Kemitraan XIE XIE BOBA, judul perjanjian tersebut juga kurang tepat karena XIE XIE BOBA dalam hal ini tidak mengembangkan bisnisnya dengan cara kemitraan, sehingga tidak tepat jika memakai kata kemitraan dalam perjanjian yang dibuatnya. 
Berdasarkan penjelasan diatas maka penulis menyimpulkan bahwa akibat hukum dari perjanjian XIE XIE BOBA yang tidak memenuhi ketentuan minimum menurut PP 36/2018 terkait klausula minimum adalah apabila klausula minimum tersebut termasuk klausula pokok dan juga termasuk unsur esensial yang harus ada dalam suatu perjanjian maka perjanjian tersebut dapat berakibat batal demi hukum karena tidak memenuhi ketentuan peraturan perundang-undangan, tetapi apabila klausula minimum tersebut termasuk dalam klausula penunjang yang bersifat melengkapi maka perjanjian tersebut tetap sah dan berlaku sepanjang tidak ada pihak yang dirugikan atas tidak adanya klausula minimum tersebut. Pada dasarnya perjanjian lisensi merek dibuat berdasarkan prinsip kebebasan berkontrak, sehingga perjanjian XIE XIE BOBA secara hukum tetap sah sepanjang tidak melanggar Pasal 1337 BW. Oleh karena itu syarat sahnya suatu perjanjian hal ini merupakan hal yang penting karena itu merupakan pilihan terakhir agar tetap perjanjian tersebut itu tetap sah dan mengikat para pihak. Apabila perjanjian XIE XIE BOBA juga tidak memenuhi syarat sahnya suatu perjanjian terutama terkait sebab yang diperbolehkan maka perjanjian tersebut dapat berakibat dapat dibatalkan atau batal demi hukum.

\section{Kesimpulan}

Dari alur bahasan dalam pembahasan penelitian ini, dapat disimpulkan bahwa perjanjian lisensi merek merupakan perjanjian yang tidak diatur secara khusus dalam BW, sehingga perjanjian lisensi merek dibuat berdasarkan asas kebebasan berkontrak. Meskipun begitu perjanjian lisensi merek juga harus memenuhi ketentuan minimum yang diatur dalam UU 20/2016 ataupun PP 36/2018 untuk dapat disebut sebagai perjanjian lisensi merek. Sehingga dengan dipenuhinya ketentuan minimum perjanjian lisensi merek sebagaimana diatur dalam UU 20/2016 dan PP 36/2018 maka karakteristik perjanjian lisensi merek adalah:

a. Bentuknya tertulis;

b. Ada para pihak yaitu pemberi lisensi dan penerima lisensi;

c. Ada objek yang diperjanjikan yaitu hak atas merek yang dimiliki oleh pemegang merek yang memliki eksklusifitas untuk memberikan izin kepada 
pihak lain untuk menggunakan hak merek yang dimilikinya untuk mengelola dan mengoperasikan usaha penjualan produk minuman dengan merek tersebut;

d. Perjanjian yang berlaku di seluruh wilayah Negara Republik Indonesia, kecuali bila diperjanjikan lain;

e. Mencatatkan perjanjian lisensi merek ke Menteri;

f. Memenuhi kententuan klausula minimum yang ditentukan berdasarkan Pasal 7 ayat (2) PP 36/2018 yaitu:

1. tanggal, bulan, tahun dan tempat perjanjian lisensi ditandatangani;

2. nama dan alamat pemberi lisensi dan penerima lisensi;

3. objek perjanjian lisensi;

4. ketentuan mengenai lisensi bersifat eksklusif atau non ekslusif, termasuk sublisensi;

5. jangka waktu perjanjian lisensi;

6. wilayah berlakunya perjanjian lisensi;

7. pihak yang melakukan pembayaran biaya tahunan untuk paten.

g. Tidak memenuhi ketentuan yang dilarang.

Sedangkan akibat hukum dari suatu perjanjian lisensi merek XIE XIE BOBA yang tidak memenuhi ketentuan minimum menurut UU 20/2016 dan PP 36/2018 terkait dengan pencatatan perjanjian lisensi merek adalah perjanjian tersebut tidak memiliki akibat hukum terhadap pihak ketiga tetapi perjanjian tersebut tetap sah dan hanya berlaku bagi para pihak saja yaitu pemberi lisensi dan penerima lisensi. Sedangkan akibat hukum terhadap perjanjian XIE XIE BOBA yang tidak memenuhi ketentuan ketentuan minimum menurut PP 36/2016 terkait klausula minum adalah apabila klausula minimum termasuk klausula pokok dan juga termasuk unsur esensial yang harus ada dalam suatu perjanjian maka perjanjian tersebut dapat berakibat batal demi hukum karena tidak memenuhi ketentuan peraturan perundang-undangan, tetapi apabila klausula minimum tersebut termasuk dalam klausula penunjang yang bersifat melengkapi maka perjanjian tersebut tetap sah dan berlaku sepanjang tidak ada pihak yang dirugikan atas tidak adanya klausula terkait sifat eksklusif atau non eksklusif tersebut. 


\section{Daftar Bacaan}

\section{Buku}

Agung Sujatmiko, 'Peran Penting Perjanjian Lisensi Dalam Melindungi Merek Terkenal' (2010) 22 Mimbar Hukum.

Gunawan Widjaja, Seri Hukum Bisnis Lisensi (Raja Grafindo Persada 2001).

Hernoko AY, Hukum Perjanjian: Asas Proporsionalitas Dalam Kontrak Komersial (Prenadamedia Group 2014).

Jened R, Hukum Merek (Trademark Law) Dalam Era Global Dan Integrasi Ekonomi) (Kencana Prenadamedia Group 2015).

Lindsey T, Hak Kekayaan Intelektual Suatu Pengantar (Alumni 2002).

Marzuki PM, Penelitian Hukum: Edisi Revisi (Prenada Media 2017).

Y. Sogar Simamora, Hukum Kontrak Prinsip-Prinsip Hukum Kontrak Pengadaan Barang Dan Jasa Pemerintah Di Indonesia (Laksbang Pressindo 2017).

\section{Jurnal}

Agung Sujatmiko, 'Peran Penting Perjanjian Lisensi Dalam Melindungi Merek Terkenal' (2010) 22 Mimbar Hukum.

\section{Laman}

Prastoyo B, 'Akibat Hukum Pencatatan Perjanjian Lisensi' <https://staff.blog. ui.ac.id/brian.amy/2008/07/15/akibat-hukum-pencatatan-perjanjianlisensi/> accessed 6 January 2021.

Go Biz, 'Manisnya Bisnis Minuman Boba \& 5 Tips memulainya' <https:// gobiz.co.id/pusat-pengetahuan/tren-bisnis-minuman-boba/> diakses 16 September 2020.

\section{Perundang-undangan}

Undang-Undang Nomor 20 Tahun 2016 tentang Merek Dan Indikasi Geografis, Lembaran Negara Republik Indonesia Tahun 2016 Nomor 252, Tambahan Lembaran Negara Republik Indonesia Nomor 5953.

Peraturan Pemerintah Republik Indonesia Nomor 36 Tahun 2018 tentang Pencatatan Perjanjian Lisensi Kekayaan Intelektual, Lembaran Negara Republik Indonesia Tahun 2018 Nomor 115, Tambahan Lembaran Negara 
82 | Cindy Fransisca dan Ghansham Anand: Aspek Perjanjian Lisensi...

Republik Indonesia Nomor 6229.

Peraturan Menteri Hukum Dan Hak Asasi Manusia Republik Indonesia Nomor 8 Tahun 2016 tentang Syarat Dan Tata Cara Permohonan Pencatatan Perjanjian Lisensi Kekayaan Intelektual, Berita Negara Republik Indonesia Tahun 2016 Nomor 301.

How to cite: Cindy Fransisca Subagijo dan Ghansham Anand, 'Aspek Perjanjian Lisensi Merek Pada Nota Kesepakatan Kerjasama Xie Xie Boba Indonesia' (2022) Vol. 5 No. 1 Notaire. 